DOI: 10.15503/onis2011-121-130

\title{
LęK PRZed Bogiem, ŚMiercią I SZATANEM W DAWneJ Rzeczpospolitej (XV - XVIII w.)
}

\author{
SEWERYN LESZCZYŃSKI \\ seweryn.leszczynski@gmail.com
}

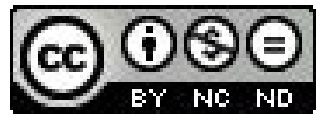

Lęk jako stan psychiczny towarzyszy człowiekowi od chwili jego narodzin. Według psychologów „lęk jest nieproporcjonalny do wielkości niebezpieczeństwa albo nawet jest reakcją na niebezpieczeństwo pozorne" ${ }^{\prime 1}$. W przypadku lęku często nie znamy jego źródła, ale już odczuwamy jego niebezpieczeństwo. W ciagu życia człowiek musi zmagać się z wieloma lękami, nigdy jednak nie paraliżował go on tak bardzo, jak w obliczu śmierci i Boga. W historii miały miejsce wydarzenia wywołujące ten szczególny lęk niemal nieustannie. Warto przyjrzeć się im bliżej.

\section{Bóg}

Lęk przed Bogiem znakomicie wpisuje się w struktury społeczne czasów nowożytnych. Bóg zawsze staje się determinantem zachowań jednostki i zbiorowości, bez niego niemożliwe byłoby pełne ukazanie mentalności ludzi w żadnej epoce. Jakie emocje wywoływał, co pomagało ludziom w przezwyciężaniu lęku przed Nim, co wreszcie wpływało na postawy moralne ludzi do początków ery przemysłowej? Na te pytania postaram się dać odpowiedź w tej krótkiej charakterystyce lęku przed Bogiem.

„Niezwykłą wagę przyznawaną ówcześnie tematowi Sądu Ostatecznego i kataklizmom, które miały go poprzedzać, można wytłumaczyć teologią Boga groźnego, wspartą przez taśmowo następujące po sobie nieszczęścia, jakie spadły na Zachód począwszy od Czarnej Zarazy"2. Duchowni zaczęli kłaść większy nacisk na ideologiczne oddziaływanie na wiernych ${ }^{3}$, wykorzystując głównie środki duchowe, takie jak „publiczne napomnienie, ekskomunika, interdykt” ${ }^{\prime \prime}$. Na początku wieku XVI, ale również w wieku XVII, teologowie i juryści nauczali, że Bóg używa demonów i czarowników, jako wykonawców swojej sprawiedliwości, w Jego naturze, więc jest mścić się: „Tedy sąd poważny teraźniejszy gajny wójtowski pyzdrski za takie złe i niecnotliwe sprawy czarowania, ich Boga odstąpienie a diabła słuchanie, dekretem swoim i zgodnymi sentencjami nakazuje, aby z tego mizernego świata, jaka robota, taka zapłata, ogniem były zniesione, i w cale na stosie spalone" ${ }^{\prime \prime}$. J. Delumeau zadaje nawet kontrowersyjne pytanie, czy Bóg byłby jeszcze godzien Swojego imienia, gdyby cecha ta (mściwość) go nie charakteryzowała ${ }^{7}$. Czasy te, szczególnie w Niemczech, naznaczone są oczekiwaniem na Boga, ideą milenaryzmu i powszechnego lęku przed końcem wieków, które wkrótce miały nadejść. Ta powszechna psychoza została wykreowana przez ówczesnych intelektualistów, niemniej jej zasięg sięgnął wszystkich stanów czy warstw społecznych. Bojaźń boża nie wszędzie, jak się okazuje, zachowywała swoją ściśle religijną funkcję. Jej znaczenie nie uległo

\footnotetext{
K. Horney, Neurotyczna osobowość naszych czasów, Warszawa 1982, s. 45.

J. Delumeau, Strach w kulturze Zachodu XIV-XVIII, Warszawa 1986, s. 207.

Z. Wójcik, Historia powszechna XVI-XVII wieku, Warszawa 1995, s. 48.

K. Dola, Mentalność duchowieństwa polskiego w dobie renesansu; [w:] K. Matwijowski, B. Rok (red.), Studia z dziejów kultury i mentalności czasów nowożytnych, Wrocław 1993, s. 20.

5 J. Delumeau, Strach..., dz. cyt., s. 208.

J. Feldman, Czasy saskie, Wrocław 2004, s. 65.

J. Delumeau, Strach..., dz. cyt., s. 209.
} 
zmianie wszędzie tam, ,"gdzie miała staćna straży prawa i porządku społecznego"8. Tam zaś, gdzie spotykamy się z laicyzacją państwa, lęk przed Bogiem zanikał.

Lęk przed Bogiem to nie tylko oficjalne proroctwa, zapowiadające koniec czasów, to przede wszystkim obawa przed grzechem i wynikająca z tego kara boża. Chrześcijanie faktycznie troszczyli się o swoje zbawienie. Tym, którzy nie bali się kary bożej, życzono spotkania z diabłem? W Polsce zaliczali się do nich przede wszystkim zboczeńcy, mordercy, złodzieje i heretycy ${ }^{10}$. Pełna sprzeczności epoka baroku, której filozofię zrodziły burzliwe czasy reformacji, szczególnie wyraźnie oddziaływała na stan duchowy zarówno bogatego mieszczanina, jak i prostego chłopa. Wspomniane już liczne pielgrzymki, swoiste dramaty i przeżycia związane z męką Chrystusa były odpowiedzią na poczucie strachu, wywołane przez nieustabilizowaną sytuację polityczna, klęski głodu i zarazy. Centralnym problemem byłjednak grzech i lęk przed potępieniem. W kronice żywieckiej Dzieciątko ostrzega Jana Cula: „Teraz się do mnie uciekasz, a pierwej żeś o mnie zapomniał, widzisz swoją stratę dla pijaństwa, że już masz bydź potępiony. A wtym rzekł: Najświętsza Panno Maria, ratujże mnie, do Ciebie się uciekam i pomocy od Ciebie upraszam - po czym białogłowa bardzo jasno zjawiła się, idąca ku niemu, a ci diabli, obaczywszy onę, wszyscy rozpierzchli się na strony, iż żaden nie został"111.

„Strach przed groźnym starotestamentowym Bogiem łagodziło przekonanie, że istnieje dobra „Panienka dworu niebieskiego", która wstawi się za grzesznikami”"12. Jak uważali w XVIII wieku polscy teolodzy i moraliści ,,kara za grzech będąca skutkiem jego popełnienia jest rozważana, jako wieczne potępienie i kara doczesna"133. Już za swojego życia, grzesznika mogło spotkać nieszczęście. Co więcej, nawet czyny moralnie dobre, których wykonawcą był ów człowiek, nie rekompensowały trwania w stanie grzechu i nie uwalniały od darowania kary doczesnej ${ }^{14}$. Jednym z warunków uniknięcia bożego gniewu był sakrament pokuty i pojednania. Po Soborze Trydenckim jego znaczenie jeszcze wzrosło, przede wszystkim, jako skutek przeciwstawienia się reformacji, która próbowała zanegować jego autorytet. Od tej pory kler wyraźnie mówi o oczyszczającej roli sakramentu pojednania. $W$ tych burzliwych czasach była ona często niezastąionym lekarstwem. Spowiedź przynosiła wielką psychiczną pociechę, przywracała grzesznikowi spokój wewnętrzny i sprawiała ogromną ulgę $e^{15}$. Według osiemnastowiecznych duchownych sakrament ten stanowił najskuteczniejszy sposób na zwalczanie grzechu ${ }^{16}$. Lęk przed Bogiem i strach przed skutkami jego gniewu wydawał się oddalać. Czasami jednak mogło dojść tylko do zamiany kary wiecznej na karę doczesną ${ }^{17}$ - pokuta, już nie wystarczała. Aby zażegnać niebezpieczeństwo płynące z niebios stosowano również środki pozasakramentalne. Zaliczano do nich sakramentalia, do których należała codzienna modlitwa, pokropienie wodą święcona, spożywanie poświęconego chleba, spowiedź powszechna na początku mszy świętej a także dawanie jałmużny i przyjmowanie błogosławieństw oraz remedia generalia a więc uczynki pobożności chrześcijańskiej i akty cnót ${ }^{18}$.

8 S. Grzybowski, Strach w XVI wieku: nowe wzorce osobowe, [w:] A. Wyczański (red.), Społeczeństwo staropolskie, t. 1, Warszawa 1976, s. 139.

9 Z. Osiński, Lęk w kulturze społeczeństwa polskiego w XVI-XVII wieku, Warszawa 2009, s. 77.

Tamże, s. 76

A. Komoniecki, Chronografia albo Dziejopis Żywiecki, Żywiec 1987, s. 303.

Z. Osiński, Lęk..., dz. cyt., s. 81.

A. Derdziuk, Grzech w XVIII wieku, Lublin 1996, s. 114.

Tamże, s. 116.

J. Delumeau, Wyznanie i przebaczenie, Gdańsk 1997, s. 29.

A. Derdziuk, Grzech..., dz. cyt., s. 300.

Tamże, s. 295.

Tamże, s. 306-307. 
Oczywiście należy wspomnieć jeszcze o chrzcie, Eucharystii i namaszczeniu chorych. Zwłaszcza woda święcona miała zabezpieczyć wiernych przed przeciwnościami losu ${ }^{19}$. Te wszystkie metody i działania miały na celu zjednanie woli Najwyższego i uproszenie łask. Zabiegi nasilały się podczas świąt Wielkiej Nocy, , ,męka Syna Bożego była ważnym elementem nie tylko w postawie pokutnej czy błagalnej, ale także w pochwalnej, a zwłaszcza dziękczynnej"20 ${ }^{\prime 2}$. Procesje również posiadały charakter ekspiacyjny, w XVIII wieku były bardzo popularne: „W Wielki Piątek takaż procesja z kapników obchodziła stacje ze śpiewaniem o Męce Pańskiej, biczując się przy każdej stacji”21. Tak z kolei opisuje procesje J. Kitowicz: „To bywało bardzo częste, osobliwie w wielkich miastach, z wystawieniem Najświętszego Sakramentu, z kazaniami i procesjami wewnątrz kościoła, które się nazajutrz takowe nabożeństwo odprawiać miało, na które nabożeństwo schodzili się gromadnie prawowierni obojej płci, a nawet wielcy panowie i panie"22.

Jeśli powyższe działania nie przynosiły pożądanych efektów, uciekano się do świętych, zwłaszcza do opieki Maryi Panny. Jak było widać we wcześniejszym przykładzie, wysłuchiwała ona próśb grzeszników. „Czyż Jezus, nawet zagniewany na ludzkie grzechy, mógłby porwać się na tych, których Jego umiłowana Matka ukrywała pod swym płaszczem?23. Pewna mieszczka żywiecka (...) ołtarz w kaplicy dała kosztem swoim Najświętszej Pannie Maryjej zrobić i pozłocić i koło wiszące wśród kościoła, do którego na świece złotych sto fundowała na wyderkaff, ażeby, co rok po złotych 7 oddawano, a w święta tajemnic różańcowych ku elewacyjej zawsze zaświecano, jako o tym roku 1647 opisano"22. Wiara w jej pomoc była tak silna, że powstały liczne wyobrażenia Madonny, m.in. wizerunek Niepokalanego Poczęcia. Niewątpliwie silniejna wyobraźnie działał jednak obraz Maryi w płaszczu, który chronił przed gniewem bożym.

Lęk przed Bogiem mógł być oddalony także dzięki wstawiennictwu świętych. Pomijając opis specjalizacji, którymi się zajmują i nie uwzględniając przestrzeni geograficznej ich działalności, można powiedzieć, że ich liczba ${ }^{25}$ dowodzi ogromnej popularności kultu, jakim się ciesza. Ilość taka można tłumaczyć chęcią wytworzenia poczucia bezpieczeństwa, którego w tamtych czasach bardzo brakowało. Święci są skutecznymi opiekunami, oczekują jednak, że ludzie będą wierzyć $w$ ich moc i wypełniać podjęte wobec nich zobowiązania ${ }^{26}$.

Poczucie zagrożenia płynące od Boga można odczytać na jeszcze jeden, i z pewnością nie ostatni, sposób. Analizując pierwsze księgi Genesis, zauważamy, że Bóg zasadził swój ogród na wschodzie. Tych słów przez blisko trzy tysiąclecia Żydzi, a następnie chrześcijanie, nie poddawali w wątpliwość jako historyczną prawdę ${ }^{27}$. Aż do czasów nowożytnych na ziemi w umysłach ludzi istniał biblijny raj. Jednak pod wpływem reformacji na nowo odczytano te frazy, wysuwając wniosek, że ziemski raj zniknął28, stał się tylko symbolem. Powoli i opornie oddalało się miejsce, które stanowiło swoisty rezerwuar bezpieczeństwa. Bóg ukazał swoją nową twarz: da-

\footnotetext{
19 B. Rok, Mentalność duchowieństwa polskiego w XVIII wieku, [w:] K. Matwijowski, B. Rok (red.), Studia z dziejów kultury i mentalności czasów nowożytnych, Wrocław 1993, s. 50.

20 J. Stręciwilk, Męka pańska w polskiej literaturze barokowej [w:] H. Wojtyska, J. Kopeć (red.), Męka Chrystusa wczoraj idziś, Lublin 1981, s. 112.

21 J. Feldman, Czasy..., dz. cyt, s. 32.

22 J. Kitowicz, Opis obyczajów za panowania Augusta III, Warszawa 1985, s. 31.

23 J. Delumeau, Skrzydła anioła, Warszawa 1998, s. 300.

A. Komoniecki, , Chronografia..., dz. cyt., s. 212.

25 Jak podaje J. Delumeau: procesje z parafii Saint-Pierre, Allein, Quart i Roisan przyzywały nawet 227 świętych (XVI w.). J. Delumeau, Skrzydła anioła..., dz. cyt., s. 184, [cyt. za:] R. Amiet, Processionale augustanum, t. 1, Aosta 1983, s. 121.

26 J. Delumeau, Skrzydła anioła..., dz. cyt., s. 230.

27 Tamże, s. 7.

28 Tamże, s. 214.
} 
lekiego, nieosiagalnego i wrogiego władcy. Ta pustka po raju musiała zostać czymś zastąpiona. Musiano na nowo zinterioryzować swój światopogląd, znaleźćjakąs bezpieczną przystań. W ten sposób lęk przed Bogiem narastał. Jak sobie z tym poradzono? Z całą pewnością pomogło ponowne przybliżenie sfery sacrum, czy wręcz ściagnięcie jej na ziemski padół, w postaci nowych mitów i filozoficznych prą̧ów, których kult nabierał teraz niewyobrażalnego tempa.

Bóg i wszystko, co z Nim jest związane, było obecne bardzo mocno w życiu każdego chrześcijanina. Fale klęsk, które spadły na Europę Zachodnią i Rzeczpospolitą w postaci wojen, epidemii i innych chorób w wiekach (XIV) XV - XVIII nie mogły pozostać bez wpływu na stosunek do Boga. Teologia ukazała Boga pełnego gniewu, który potrafi mścić się na grzesznikach. Lęk przed Bogiem zaczyna narastać. Taki obraz wygenerował postawy uniżenia i pojednania, nowego wymiaru nabrał grzech. Wzrosła rola pokuty i ceremonii, których celem było przebłaganie za winę. Wreszcie zaczęto uciekać się do opieki Matki Boskiej i świętych. Lęk przed Bogiem obejmował lęk przed potępieniem, śmiercia, zmuszał do rozmyślań o rzeczach ostatecznych. To właśnie w śmieci krzyżują się wszystkie nasze lęki i obawy, które bardzo często zostają zepchnięte do podświadomości.

\section{ŚMIERĆ}

Czym w rzeczywistości jest śmierć, z punktu widzenia ówczesnych teologów? W znaczeniu fizycznym - jest to oddzielenie duszy od ciała, w znaczeniu psychofizycznym (śmierć biologiczna) - zatrzymaniem wszelkich czynności życiowych w efekcie, których ciało zaczyna się rozkładać29. Teolodzy, opierając się na Piśmie Świętym, głosili, że śmierć oznacza zabranie ducha przez Boga, tylko On, dla wierzącego, potrafi dawać i odbierać życie ${ }^{30}$. W czasach nowożytnych ludzie uświadomili sobie tę prawdęjeszcze bardziej, aczkolwiek „,strach przed śmiercią towarzyszył człowiekowi niezależnie od epoki" ${ }^{\prime 31}$. Poza tym śmierć, prędzej czy później, dotykała każdego; szczególne wrażenie sprawiało nagłe odejście: „Tenże roku (...) ksiądz Sebastian Bergier alias Bergius, proboszcz żywiecki w łaźni zamkowej nagle umary"32. Poza wspomnianymi już naturalnymi klęskami, które dla społeczeństwa stanowily zawsze karę boską i w jakiś sposób przybliżały śmierć, należy powiedzieć o szerzeniu określonego duszpasterstwa. Kaznodzieje szukali najlepszych sposobów, żeby wywrzeć jak największe wrażenie, wykorzystując przy tym liczne sztuczki i uwiarygodnić „,tę mieszankę wpajania poczucia winy, gróźb i pocieszania, jaka w ciągu całych wieków stanowiła najczęściej spotykaną treść kaznodziejstwa" ${ }^{\prime \prime 33}$. Lęk przed śmiercią wzmacniały opisy mąk piekielnych i wizji czyśćcowych, jednocześnie pouczano, że czynienie dobrych uczynków ma zapewnić szczęście wieczne ${ }^{34}$. Szerzenie wizji mąk piekielnych było przejawem troski ówczesnego duszpasterstwa o zbawienie człowiek ${ }^{35}$. Stałe przypominanie o życiu pozagrobowym miało skłonić wiernych do przemyśleń nad własnym życiem. Równocześnie przypominano o tym w tekstach literackich i sztuce. Pewien jezuita o nazwisku Outreman wykorzystuje przykład świętego Grzegorza I Wielkiego i Innocentego I, by „uzasadnić niezbędną trwogę, którą trzeba wpoić ludowi grzeszników" ${ }^{\prime \prime 36}$.W kulturze polskiej zaś możemy przywołać tutaj treny J. Kochanowskiego.

\footnotetext{
29 M. Rusiecki, Obraz śmierci w katechezie kościoła katolickiego w XVI-XVIII wieku., [w:] H. Suchojad (red.), Wesela chrzciny i pogrzeby w XVI-XVIII wieku, Warszawa 2001, s. 290. 
Śmierć jest wreszcie gorzkim owocem grzechu pierworodnego, dziełem diabła - kusiciela ${ }^{37}$. Spowodował on upadek człowieka, co w konsekwencji przyczyniło się do wygnania go z raju. Człowiek stał się śmiertelny. Jednak w osobie Jezusa Chrystusa, otrzymał wspaniały dar, który daje mu życie wieczne. Musi tylko pokonać swoje słabości i wyzwolić się z pętli Szatana. Śmierć jest nieunikniona, ale można ją pokonać. W dokonaniu tego dzieła nie pomagała niestety tradycyjna doktryna chrześcijańska na gruncie, której teolodzy podjęli ogromny wysiłek, żeby zdjąć z Boga odpowiedzialność za grzech dziedziczny, co osiagnięto oskarżając człowieka ${ }^{38}$. Teksty moralizatorskie próbowały wmówić człowiekowi, że tylko on jest winny swego losu, podkreślając przy tym, że „źródłem grzechu jest także świat oraz ludzkie ciało"39. Lęk przed samym sobą w postaci „choroby skrupułu" przybrał takie rozmiary, że powstała cała literatura, która starała się przywrócić spokój zaniepokojonym duszom. Stan zaniepokojenia i ulotności ludzkiego życia oddaje kaznodziejstwo jezuickie: „Śmieszny-żem ja człowiek! Czas skrzydlasty, szklane klepsydry! W lekkich proszkach godziny! Obrotne w zegarach koła! Moment nie mój, a ja się śmieję! A ja o doskonalszym życiu nie myślę!" ${ }^{\prime \prime 4}$. Zalecano „unikania nadmiaru umartwień, pielęgnowanie sposobami medycznymi melancholiczne humory i udręki wyobraźni, nauczano odróżniać grzechy śmiertelne od powszednich, wreszcie zakazywano roztrząsania przeszłości, nie powtarzania modlitw, jeśli zakradło się roztargnienie i propagowano bycie posłusznym wobec rozsądnych ocen dobrze wybranego przewodnika sumienia" ${ }^{\prime 1}$. Lęk przed śmiercią i grzechem przeszedł swoistą ewolucję przeistaczając się w lęk przed własnym sumieniem. Pomimo grzechu śmiertelnego, człowiek jako istota świadoma swojego losu, nigdy nie zgodzi się na swoje unicestwienie ${ }^{42}$. Wiara $\mathrm{w}$ zbawienie jest jakby dopełnieniem jego woli, ukoronowaniem odwiecznego pragnienia życia wiecznego. Jednak z czasem ta chęć życia może się osłabić wraz z upływem naturalnych sił organizmu. Dlatego człowiek starszy może łatwiej pogodzić się ze śmiercia, tracąc siły witalne, ale zyskując większą świadomość swojego przeznaczenia.

Odbicie lęku przed śmiercią w sztuce i literaturze jest tylko wyobrażeniem twórców, które nie od razu wywoła wzrost poczucia świadomości zbliżającego się końca życia. Dopiero ukonkretyzowanie tego fenomenu pozwoli na rzeczywiste ustosunkowanie się do niego szerszych mas społecznych. W ciagu XVII i XVIII wieku ,szalony strach wyłamał się z kręgu wyobraźni i przenikną do realnie przeżywanej rzeczywistości, w uczucia świadome i wyrażane, jednakże w formie ograniczonej, dającej się ujarzmić nieobejmującej całego mitu, w formie pozornej śmierci, niebezpieczeństwa, które zagraża temu, kto stał się żywym - umarłym" ${ }^{\prime \prime 3}$. Widzimy, że interioryzacja faktu śmierci nie przebiegała właściwie, jej stan burzyło wkroczenie życia w sferę śmiertelna, w postaci trupów wychodzących z trumien i tańczących na obrazach i na kartach literatury. Była to tylko jedna, z pozornych oczywiście, form zabezpieczeń przed tym przeznaczeniem. Istnienie takiego stanu rzeczy można wytłumaczyć faktem, że śmierć stanowi jedną z najbardziej przerażających pustek, która pomimo swej realności, jest niewyobrażalna i niesprawdzalna $\mathrm{w}$ indywidualnym doświadczeniu ${ }^{4}$. Uciekano się do wszelkich możliwych metod, które miały chronić przed wiecznym potępieniem. Czytano wspomniane już poradniki

\footnotetext{
37 M. Rusiecki, Obraz śmierci..., dz. cyt., s. 291.

J. Delumeau, Grzech i strach..., dz. cyt., s. 361.

M. Rusiecki, Obraz śmierci..., dz. cyt., s. 293.

J. Feldman, Czasy..., dz. cyt., s. 40.

J. Delumeau, Grzech i strach..., dz. cyt., s. 460.

Tamże, s. 361.

P. Aries, Człowiek i śmierć, Warszawa 1989, s. 397.

A. Kępiński, Lęk, Warszawa 1987, s. 357.
} 
na temat grzechów, poza tym przygotowania do ostatniej drogi obejmowały umartwianie się, pokutę $\mathrm{i}$ inne męki, które, $\mathrm{w}$ mniemaniu ludzi tamtych wieków, miały im przynieść upragniony raj. Chodziło przede wszystkim o pogłębianie wiary i nadziei, posłuszeństwo sumieniu i zdobywanie sprawności moralnej ${ }^{45}$. Ostatnie zabiegi, jakie stosowano, chcąc optymalnie przygotować się na śmierć polegały na przyjęciu sakramentu chorych i głębszym uświadomieniu sobie misterium cierpienia i męki Pańskiej. Służyło temu wpatrywanie się w krzyż i opieka bliskich; teraz umierający mógł ze spokojem czekać na ostateczność. Spokój ducha, który osiagał, pozwalał mu całkowicie zawierzyć się Panu. Patronem dobrej śmierci był św. Józef. Jego rola była podobna do roli, jaką przy konającym, odgrywała Maryja Panna, inni święci i anioł stróż ${ }^{16}$.

Należy wspomniećjeszcze o jednej, ważnej broni przeciwko nadciągającej nieuchronnie śmierci. Jest nia, powszechna w umysłach ludzi epoki przedindustrialnej, wspomniana już, wiara w ziemski raj. Istnienie tego mitu, chociaż po części, łagodziło niepokój, który musiał wzbudzać lęk.

W mentalności szlachty bardzo ważną rolę odgrywały uroczyste ceremonie pogrzebowe, tak zwane pompa funebris. Pomijając dewocję ówczesnych magnatów, można powiedzieć, że przepych, który towarzyszył tego typu inscenizacjom miał na celu zagłuszenie faktu śmierci, a któremu to zabiegowi służyć miały liczne procesje, kazania i wreszcie bogactwo samych katafalków. Obraz takiej ceremonii daje nam relacja pogrzebu pana Denhoffa, wojewody połockiego $\mathrm{i}$ hetmana polnego dnia 6. lutego $1730 \mathrm{r}$.:

„(...). Nad katafalkiem aksamitem także szamerowanymi nakrytym baldachimem okragły, aksamitny, wierzchem ad instar korony kształtnie wysadzonej wisiał bogato galonami złotymi floryzowany. Pod nim trumna złotogłową materyją galonami i franzlami srebrnymi ustrzona stała, której po rogach insygnia hetmańskie na wezgłowiach, jako to: buława, buńczuk, zbroja, szabla, tarcza, koncerz, pancerz, na śrzodku order i czapka leżały. (...). Skonczywszy kondukt po kazaniu Salve Regina (...) żałosno przegrywała kapela. (...). Mszy czytanych niezmierna była liczba, bo zewszą świeckich i zakonów magnus był confluxus. Księży po talerze bitym, a zakonnikom po czerwonym złotym dawano. (...). Po wszystkich transakcyjach jm. pan podkomorzy W.Ks.L częstował - - 47”'.

Z punktu widzenia katechizmów wieków XVI - XVIII można wyróżnić dwa oblicza śmierci. Jedno jest surowe i przerażające, ukazane zwłaszcza w ikonografii, druga twarz to śmierć pokonana przez Chrystusa, której ostrze jest stępione ${ }^{48}$. Lęk przed śmiercią $\mathrm{w}$ tamtych czasach przybierał skrajne postaci. W kontekście męki i zmartwychwstania Jezusa Chrystusa, śmierć jest przejściem do wiecznego szczęścia. Jednak jakże sprzeczne wówczas katechezy potrafią zniekształcić ten obraz. Człowiek popada w "chorobę skrupułu”, oddaje się tylko refleksjom nad męka, pomijając akt zmartwychwstania. Na szczęście w obliczu bezpośredniego zagrożenia potrafi się przygotować na nadchodzący kres. Opieka św. Józefa i Maryi Panny, pomagają mu pokonać lęk przed przejściem. Jednak sam fakt istnienia śmierci doczesnej pozostaje niezmienny od początków dziejów ludzkości. Grzech pierworodny zdeterminował los człowieka.

\section{Szatan}

Piekło nosimy sami w sobie, niby szatę zrośniętą z ciałem, niby skórę kameleona, która zmienia barwę zależnie od lęków danej epoki ${ }^{49}$. Ta metafora sugeruje, że zło na ziemi pochodzi od

45 M. Rusiecki, Obraz śmierci..., dz. cyt., s. 294.

46 J. Delumeau, Skrzydła anioła..., dz. cyt., s. 358.

47 A. Gierowski, Rzeczpospolita w dobie upadku 1700-1740, Wrocław 1955, s. 82-85.

48 M. Rusiecki, Obraz śmierci..., dz. cyt., s. 301-302.

49 G. Minois, Historia piekła, Warszawa 1996, s. 8. 
nas samych i tylko od nas zależy czy pozbawimy go wpływu na nasze życie. Jak bardzo ta siła nas paraliżuje, dlaczego piekło budziło kiedyś grozę? Jak wyobrażano sobie Szatana? Dlaczego z czasem o nim zapomniano?

Lęk przed mocami i mękami piekielnymi stanowi część opisanych wyżej lęków przed Bogiem i śmiercią. Śmierć przerażała już choćby z tego powodu, że kryła nieznane. Chrześcijanie obawiali się Boga, i to do tego stopnia, że wpadli $\mathrm{w}$ „,chorobę skrupułu”. Zaczęli się bać samych siebie. Lęki przed nieznanym, przed Wszechmogącym oraz przed skutkami grzechu nałożyły się na siebie tworząc lęk przed piekłem. W obliczu śmierci grzesznik, który nie pojednał się z Bogiem często nie widział dla swojego losu alternatywy. Jego doczesne życie na ziemi dobiegło końca, ponadto mogła przerażać go wizja okrutnego Boga, wreszcie mógł się znaleźć, z dużą dozą prawdopodobieństwa, w mękach piekielnych. W takich chwilach ten ostatni rodzaj lęku przesłaniał wszystkie inne. W XVI-XVII wieku obawa przed piekłem prześladowała jednak człowieka przez całe życie. Jaki kształt przybierała ówczesna pedagogika kościelna dotycząca tego zagadnienia? Jak mówi G. Minois piekło jest wszechobecne w kazaniach, staje się wręcz ich naczelnym tematem ${ }^{50}$. Przekonanie, że demon ustawicznie kusi człowieka, przeniknęło całą literaturę teologiczną renesansu ${ }^{51}$. Wynikało to ze wspomnianej już troski kleru o nawrócenie ludu. Chodziło o wpojenie wiernym szczerego lęku zdolnego wzbudzić zbawienny respek ${ }^{52}$. Gdy nie pomagała wizja Boga pełnego gniewu, gdy ikonografie nie nadążały za cynizmem społeczeństwa, uciekano się do ostateczności, strasząc po prostu konsekwencjami grzechu. Pokrótce tylko przedstawię wizje mąk infernum, które w XVI i XVII wieku roztaczano przed wiernymi. W piekle kary były jakby odzwierciedleniem kar ziemskich, z tą różnica, że były stokroć sroższe i nie miały końca. „Kara ta różni się od sankcji, którymi rozporządza sprawiedliwość ludzka: wymierzają ją moce nadprzyrodzone lub mściwy los" ${ }^{\prime \prime 5}$. Piekło staje się czymś w rodzaju ogromnej sali tortur, w której Bóg rękami diabłów oddaje każdemu według jego uczynków ${ }^{54}$. Podobnie jak w ziemskim systemie karnym, karano tę część ciała, która zawiniła. Istniały męki zadawane poszczególnym zmysłom, kolejny podział odnosił się do rodzajów grzechu: a więc inne męki groziły za rozpustę, inne za obżarstwo itd. Męczarnie przewyższały wszystko, co można cierpieć na ziemi wskutek choroby, klęsk żywiołowych, niesprawiedliwości bądź niegodziwości ${ }^{55}$. Raczej nie negowano istnienia ognia piekielnego. W wieku XV a jeszcze w XVI ogień miał spalać grzechy człowieka, tym samym pomagając mu w przejściu do raju. W XVII wieku jednak ogień oczyszczający stał się karzący i zstąpił o jedno piętro w dół ${ }^{66}$. Obok ognia występowała też wizja zimna, która miała panować w świecie piekielnym. Te wszystkie obrazy wzmacnia jeszcze jeden szczegót. Otóż w wieczności nie ma punktu odniesienia, czas traci sens. „Ten, kto żyje wiecznie, nie ma już przyszłości”"57. Dusza nie jest świadoma upływającego cierpienia, bo jego ziemskie pojęcie już się skończyło. Będzie ono trwać tak długo jak szybko skończy się wieczność. Jej istotę jednak, jak wiemy, stanowi nieskończoność.

Aplikacja obrazów piekła do społeczeństwa przez ludzi duchownych słabnie w wieku XVIII. Piekło jako kara $w$ wiekach poprzednich przeniosło się na ziemię, dlatego teraz straciło swój zasadniczy sens ${ }^{58}$. Coraz mniej klęsk i chorób sprawiało, że świat stawał się bardziej przyjazny.

\footnotetext{
Tamże, s. 208.

J. Delumeau, Strach w kulturze..., dz. cyt., s. 236.

G. Minois, Historia..., dz. cyt., s. 246.

Tamże, s. 11.

J. Sokolski, Staropolskie zaświaty, Wrocław 1994, s. 159-161.

J. Delumeau, Grzech i strach..., dz. cyt., s. 546.

Tamże, s. 545.

G. Minois, Historia..., dz. cyt., s. 247.

Tamże, s. 371.
} 
Reformy religijne, laicyzacja, przegnały z powrotem w zaświaty infernalne moce, by powrócić z nową siłą w wieku XX' $X^{59}$.

Czy kazania odniosły zamierzony skutek? Wydaje się, że tak, świadczy o tym opisany w lęku przed Bogiem i śmiercią rozwój różnych forma zabezpieczeń. Można chyba zaryzykować twierdzenie, że to lęk przed piekłem wywierał na wiernych największy wpływ. Określał zachowania w stosunku do samej śmierci i Najwyższego. Jednak wraz z polepszeniem jakości życia ta złowroga wizja zaczęła się oddalać, ludzie zapomnieli o moralności. Zachowanie ówczesnych nie stanowi chyba wyjątku w dziejach, dlatego warto obserwować dzisiejszy świat.

Szatan, podobnie jak Bóg, budził skrajne uczucia i emocje. Obawiano się go: „(...) wojska czart zmyślał dla postrachu ludzi i poddanym paskudy wyrządzał"60, szanowano ze względu na potęgę, wreszcie wywoływał lęk przed złem, którą kryła pokusa ${ }^{61}$. Upraszczając można powiedzieć, że w tych czasach wspótistniały dwa odmienne wizerunki Szatana: jeden ludowy, drugi elitarny, bardziej tragiczny ${ }^{62}$. Ten ostatni w wiekach XIV - XVII przejął elementy zapożyczone ze Wschodu, pojawiły się nawet analogie do buddyzmu ${ }^{63}$. Książę tego świata bierze sprawy na ziemi w swoje ręce. Tak można zinterpretować następstwa poczucia kruchości człowieka wobec śmierci w okresie renesansu, zaś akty przemocy w wieku następnym były „na miarę lęku, jaki odczuwano przed diabłem, jego agentami i jego wybiegami" ${ }^{\prime 64}$. Wobec przedstawienia już literackich obrazów piekła, warto zaprezentować jak widziano samego Szatana. W obrazowy sposób ukazał go H. Bosch, jego Sąd Ostateczny osiaga szczyt grozy. Jeden z demonów ma głowę ptaka z długim dziobem, inny niesie na ramieniu kij, na którym zawieszony jest przebity strzałą potępieniec, sam Szatan zaś w turbanie na głowie ma ogniste oczy, głowę dzikiej bestii, szczurze łapy i ogon ${ }^{65}$. Dla reformatów, szczególnie dla M. Lutra, Antychrystem był sam papież, dla katolików innowiercy byli rodem z piekła:, , (...) ale kto Lutrem jest, niech wierzy, jako chce i do diabła idzie" ${ }^{\prime \prime 6}$. Moce piekielne skumulowały się bowiem w Rzymie i Awinionie, siejąc strach na cały chrześcijański świat. Zejdźmy jednak na ziemię i przyjrzyjmy się różnym diabłom, nierzadko zamieszkujących domowe zapiecki. Diabeł ludowy przybierał różne postaci. Był nawet opiekunem wsi, nazywano go bożym ludkiem, skrzakiem, inkluzem, ankluzem, kłobukiem, chobardem i kraśniakiem ${ }^{67}$. Polski chłop raczej nie bał się tych diabełków. Jak powiadano każdy go wyprowadzał w pole. Diabeł wreszcie mógł przychodzić do kobiety pod postacią np. kota. Niektórych zalotników przezywano diabłem: „Dnia 25 stycznia we wtorek Jan Szymoński, rzeźnik i mieszczanin żywiecki nagle także umarł (...). A tego człowieka nazywano Biały Diabał, z tej okazyjej, że jego przodek polecał się był jednej miejskiej pannie, do której nauczał się chodzić w nocy, oknem łażąc" ${ }^{\prime \prime 6}$. Spotkanie diabła na drodze, a co dopiero kilku z nich, musiało jednak napawać lękiem. Pewien mieszczanin żywiecki nazwiskiem Lipardt przechodząc przez wieś Zabłocie napotkał górali, którzy wydali mu się jakoś dziwni. Gdy uczynił szybko znak krzyża, wszyscy zniknęli. Stwierdził, że zaszli mu drogę wysłannicy piekieł. Zaraz przypomniał sobie, że 10 lat temu, gdy był kalwinem, diabły

\footnotetext{
59 Tamże.

60 A. Komoniecki, Chronografia..., dz. cyt., s. 569.

61 A. Kępiński, Lęk..., dz. cyt., s. 350.

62 J. Delumeau, Strach w kulturze..., dz. cyt., s. 229.

63 Tamże, s. 222.

64 Tamże, s. 239.

65 Tamże, s. 222.

66 A. Komoniecki, Chronografia..., dz. cyt., s. 336.

67 Z. Osiński, Lęk..., dz. cyt., s. 109.

68 A. Komoniecki, Chronografia,... dz. cyt., s. 501.
} 
straszyły w jego kuźni; ponoć nawet egzorcyzmy nie pomagały ${ }^{69}$. Jak widać nawet po tak długim okresie czasu, diabeł mógł ukazać się człowiekowi ponownie.

Przypływ satanizmu w pierwszych wiekach ery nowożytnej nie jest czymś zaskakującym. Wobec kryzysu idei życia, wojen i reform religijnych, jego wizerunek musiał znaleźć odbicie w literaturze, sztuce i kulturze ludowej. Czy to nie właśnie jego przywołanie z zaświatów nie spowodowało tylu klęsk i wojen, które permanentnie nawiedzały wówczas Europę? Ten fenomen można wytłumaczyć faktem, że ,jednostki pokrzywdzone przez los czy społeczeństwo szukały pod patronatem Szatana ujścia dla swych anarchistycznych, rewolucyjnych, a czasem aspołecznych i amoralnych marzen'"70. Rozwój czarostwa w tamtym czasie stanowił pewien rodzaj aplikacji własnych pragnień $\mathrm{w}$ wąskie ramy społeczne. Powszechność tego zjawiska pozwoliła na legitymizację kobiet - czarownic i tym samym na wprowadzeniu sankcji za uprawiany proceder. Duchowieństwo zaatakowało ze zdwojoną siłą. W pewnym momencie odwrót stał się niemożliwy. Lęk przed piekłem i jego piekielnym władcą spowodował poczucie zagrożenia, występowanie i intensywność tego zjawiska miało jednak różną dynamikę w różnym okresie czasu. Jego ofiarami padły nie tylko czarownice, ale również heretycy i bezbronnejednostki. Na ile była to sprawka diabła, a na ile samego człowieka, pozostaje kwestią dyskusyjną. Sądzę, że gdyby nie czyny ludzkie, nie doszłoby do przypływu satanizmu. Można powiedzieć, że „,człowiek człowiekowi zgotował ten los”.

Czasy nowożytne obfitowały w dynamiczne wydarzenia. Na tyle dynamiczne i skomplikowane, że próbowano sobie z nimi radzić na wiele sposobów. Jednym z przejawów postaw ludzi tamtych wieków jest paroksyzm lęku przed Bogiem i Szatanem. Zagrożenie było na tyle duże, obecność Szatana na tyle powszednia, a oddech śmierci tak bliski, że w obliczu wojen i klęsk żywiołowych nasi antenaci często zwracali się do Najwyższego z prośbą o ochronę. Fenomen ten spowodowany jest wieloma wspomnianymi już czynnikami, nieodparcie jednak nasuwa się jedna myśl. Człowiek okresu renesansu czy baroku posiadał dużą świadomość zaświatów, potrafił dostrzec ich wpływ na ziemi oraz zaaplikować obecność istot transcendentnych do swojego życia. Dzisiaj zadanie te wydaje się chyba trudniejsze.

\section{Bibliografia}

Aries P., Człowiek i śmierć, Warszawa 1989.

Delumeau J., Grzech i strach. Poczucie winy w kulturze Zachodu XIII-XVIII wieku, Warszawa 1994.

Delumeau J., Skrzydła anioła. Poczucie bezpieczeństwa w duchowości człowieka Zachodu w dawnych czasach, Warszawa 1998.

Delumeau J., Strach w kulturze Zachodu XIV-XVIII wieku, Warszawa 1986.

Delumeau J., Wyznanie i przebaczenie. Historia spowiedzi, Gdańsk 1997.

Derdziuk A., Grzech w XVIII wieku. Nurty w polskiej teologii moralnej, Lublin 1996.

Dola K., Mentalność duchowieństwa polskiego w dobie renesansu, [w:] Matwijowski K., Rok B. (red.), Studia z dziejów kultury i mentalności czasów nowożytnych, Wrocław 1993.

Feldman J., Czasy saskie. Wybór źródeł, Wrocław 2004.

Gierowski J., Rzeczpospolita w dobie upadku 1700-1740. Wrocław 1955.

Grzybowski S., Strach w XVI wieku: nowe wzorce osobowe, [w:] Wyczański A. (red.), Społeczeństwo staropolskie, t. 1, Warszawa 1976.

Horney K., Neurotyczna osobowość naszych czasów, Warszawa 1982.

Kępiński A., Lęk, Warszawa 1987.

Komoniecki A., Chronografia albo Dziejopis Żywiecki, Żywiec 1987.

Kitowicz J., Opis obyczajów za panowania Augusta III, Warszawa 1985.

Matwijowski K., Rok B. (red.), Studia z dziejów kultury i mentalności czasów nowożytnych, Wrocław 1993.

\footnotetext{
69 Tamże, s. 332.

70 A. Kępiński, Lęk..., dz. cyt., s. 351.
} 
Minois G., Historia piekła, Warszawa 1996.

Osiński Z., Lęk w kulturze społeczeństwa polskiego w XVI-XVII wieku, Warszawa 2009.

Rok B., Mentalność duchowieństwa polskiego w XVIII wieku, [w:] Matwijowski K., Rok B. (red.), Studia z dziejów kultury i mentalności czasów nowożytnych, Wrocław 1993.

Rusiecki M., Obraz śmierci w katechezie kościoła katolickiego w XVI-XVIII wieku, [w:] Suchojad H. (red.), Wesela, chrzciny i pogrzeby w XVI-XVIII wieku. Kultura życia i śmierci, Warszawa 2001.

Sokolski J., Staropolskie zaświaty. Obraz piekła, czyśćca i nieba w renesansowej i barokowej literaturze polskiej wobec tradycji średniowiecznej, Wrocław 1994.

Stręciwilk J., Męka pańska w polskiej literaturze barokowej, [w:] Wojtyska H, Kopeć J. (red.), Męka Chrystusa wczoraj i dziś, Lublin 1981.

Suchojad H. (red.), Wesela, chrzciny i pogrzeby w XVI-XVIII wieku. Kultura życia i śmierci, Warszawa 2001.

Woityska H., Kopeć J. (red.), Mẹka Chrystusa wczoraj i dziś, Lublin 1981.

Wójcik Z., Historia powszechna XVI-XVII wieku, Warszawa 1995.

Wyczański A.(red.), Społeczeństwo staropolskie, t. 1, Warszawa 1976.

\section{Słowa kluczowe}

Bóg, śmierć, Szatan, lęk, piekło, grzech.

\section{STRESZCZENIE}

W XVI i XVII w. na Zachodzie Europy zaczęły nasilać się burzliwe zjawiska życia społecznego i politycznego. Wojny i klęski żywiołowe znalazły swoje odbicie nie tylko na kartach literatury, ale również w postaci mitów, wierzeń czy rozwoju inkwizycji. Prym wiodła czarna i biała magia, okultyzm czy wiedza ezoteryczna. W II połowie XVII w. oraz w I połowie następnego stulecia podobne zjawiska miały miejsce w I Rzeczpospolitej. Lęk przed śmiercia, Bogiem i Szatanem zaczął przybierać różne formy, człowiek zaś próbował radzić sobie z owym stanem na wiele sposobów. Zarys problematyki nie odzwierciedla z pewnością całego zagadnienia lęku w kulturze czasów nowożytnych, a jest tylko jego niewielkim wycinkiem.

\section{FEAR OF GOD, DEATH AND DEVIL IN I RzECZPOSPOLITA}

\section{Keywords}

God, death, devil, fear, hell, sin

\section{Summary}

In the $16^{\text {th }}$ and $17^{\text {th }}$ century in the west of Europe tempestuous phenomena in political and social life started increasing. Wars and natural disasters were reflected not only in the literature but also in myths, beliefs, development of the Inquisition. The most common were black and white magic, occultism, esoterism. During the second half of the $17^{\text {th }}$ century and the first half of the $18^{\text {th }}$ century similar phenomenon took place in the I Rzeczpospolita. Fear of death, God and devil appeared in different shapes, so individual was trying to cope with this situation in various ways. Of course this is just a brief outline of the problem and would not embrace all the complexity of fear in modern times. 